\title{
Factors affecting the decision to change the family physician
}

\author{
NEVRUZ YILDIRIM TOPAK ${ }^{\mathrm{B}-\mathrm{F}}$, HAKAN DEMIRCI ${ }^{\mathrm{A}, \mathrm{D}-\mathrm{F}}$ \\ ORCID ID: 0000-0003-0434-4807
}

Department of Family Medicine, University of Health Sciences, Bursa Yüksek Ihtisas Training and Research Hospital, Bursa, Turkey

A - Study Design, B - Data Collection, C - Statistical Analysis, D - Data Interpretation, E - Manuscript Preparation, F - Literature Search, $\mathbf{G}$ - Funds Collection

Summary Background. Some studies on the decision of patients to choose their primary healthcare physician demonstrate that the ability to choose their physician is associated with increased patient satisfaction, confidence in the doctor and quality healthcare. Objectives. The study was aimed at evaluating factors effecting the decision to change the family physician.

Material and methods. In the study, a questionnaire was used to examine the socio-demographic characteristics of the individuals, and the EUROPEP scale was used to measure the satisfaction with primary health services. Moreover, the Individual Innovativeness Scale was used in order to evaluate the innovativeness of individuals.

Results. In people who apply to change their family physician, satisfaction with the previous family physician was found to be $69 \%$. Distance $(52.7 \%)$, education $(25.8 \%)$ and gender $(16 \%)$ were declared as the most important reasons to change the family physician. An individual's innovation seeking behavior did not affect on their decisions to change the physician.

Conclusions. In the present study, patient satisfaction was lower than the results reported in previous studies. Distance, education and gender are at the forefront in family physician preference. Patients prioritize receiving service from trained family physicians. These issues should be taken into account while planning the future of family practice.

Key words: education, gender identity, physicians, family, patient satisfaction.

Topak NY, Demirci H. Factors affecting the decision to change the family physician. Fam Med Prim Care Rev 2019; 21(2): 173-179, doi: https://doi.org/10.5114/fmpcr.2019.84554.

\section{Background}

People are healthier in countries where the primary healthcare service is strong [1]. In spite of the fact that health policies and practices vary throughout the world, family practice constitutes the basic element of healthcare services. A strong primary healthcare service provides a cheaper healthcare service with easier accessibility and better satisfaction [2].

Individuals are granted the right to choose their physician thanks to the health reform in Turkey. Patients who are not pleased with their family physicians have the right to change their physician at the end of a three-month period within the province due to the current regulations [3]. Moreover, this three-month condition is not required for out-of-province patients or for individuals with privileged excuses (over the age of 65 , pregnant, etc.).

Some studies on the decision of patients to choose their primary healthcare physician demonstrate that the ability to choose their physician is associated with increased patient satisfaction, confidence in the doctor and quality healthcare [4-6]. Accessibility of healthcare services, type and size of the services, status/experience/quality of the healthcare staff, organization of the healthcare, treatment expenses and socio-demographic characteristics of the family physicians are effective in the choice of the physician [3]. Additionally, three variables have been identified in the selection of the family physician: professional skill, management skill and personal characteristics. It has been shown that elements including professional skill factor have the highest effect, followed by elements constituting management skills. Personal characteristics have the lowest effect [7].
Organizations, managers, staff and even individuals need to innovate and adapt innovativeness as a behavior in order to comply with the rapidly changing world and to sustain an individual, organizational and professional life $[8,9]$. Innovation is the process of embodying a new and valuable idea or invention at the right time as a product, process or service and translating it into social benefit $[10,11]$. Personal innovativeness is considered as an umbrella concept that contains in itself the characteristics of concepts such as risk-taking, being open to experiences and opinion leadership. Personal innovativeness is also the degree to which individuals in a social system adopt any innovation before others [12]. Individuals in the society are different from each other in terms of innovation according to their characteristics. This is why individuals can behave differently in adopting any innovation, being willing to change and to take risks [13].

\section{Objectives}

The study was aimed at evaluating factors effecting the decision to change the family physician.

\section{Material and methods}

The research study was performed with the help of 500 volunteers between the ages of 18-65 who were selected randomly from among individuals admitted to the Family Health Center Unit (\#16.02.174) between the dates September 2016 - February 2017 in order to change their family physician. 
The ethics committee of Bursa Yüksek Ihtisas Training and Research Hospital approved the study.

In this study, a questionnaire was used to interrogate the socio-demographic characteristics of the individuals, and the EUROPEP scale was used to measure the satisfaction with primary health services [14]. Moreover, the Individual Innovativeness Scale was used in order to evaluate the innovativeness of individuals.

The satisfaction status of the individuals with their previous family physicians was evaluated with the EUROPEP scale, which questions 5 different situations in 23 questions, from doctor-patient relationship to accessibility to the doctor. 3 more questions were added to the 23 question EUROPEP scale in the research performed by the Ministry of Health throughout Turkey in order to measure general satisfaction levels, and a questionnaire of 26 questions was applied. The participants were asked to answer the questions with 6 choices (very bad, bad, normal, good, perfect, no idea) according to the Likert scale. Patient satisfaction was analyzed within the aspects of 'Doctor-patient relationship', 'Health Service', 'Information and Support', 'Health Service Organization', 'Accessibility' and 'General Evaluation' [15].

The Individual Innovativeness Scale (IIS), which is a self-report measuring tool, was used to determine individuals' general innovativeness levels and their innovativeness categories [12]. The original questionnaire form contains 20 expressions in total related to the characteristics of the individuals in 5 different categories, from innovative to traditionalist. Each expression in the questionnaire about individual innovativeness is graded according to a 5-point Likert scale, from "Strongly Disagree" to "Strongly Agree". Scale items consisted of 12 positive expressions (items $1,2,3,5,8,9,11,12,14,16,18$ and 19) and 8 negative expressions (items 4, 6, 7, 10,13, 15, 17 and 20). With the help of the scale, the innovativeness score is calculated by adding 42 points to the score obtained by subtracting the total score of negative items from the total score of positive items. The lowest grade to be obtained with the help of the scale is 14 , and the highest score is 94 . According to the scores calculated through the scale, individuals are interpreted as "Innovator" if the score is over 80 , "Pioneer" if the score is between 69 and 80 , "Interrogator" if the score is between 57 and 68,"Skeptical" if the score is between 46 and 56 and "Traditionalist" if the score is below 46. Moreover, a general evaluation can also be made on the innovativeness levels of the individuals according to the score calculated with help of the scale. Accordingly, individuals who get a score higher than 68 are considered to be quite innovative, while those with a score lower than 64 are evaluated as low in innovativeness [12].

The compatibility of the variables to normal distribution was analyzed with the Shapiro-Wilk test, and the determiner was expressed statistically as median (minimum : maximum) or mean \pm standard deviation (minimum : maximum) values. The Mann-Whitney $U$ test was used in the comparison of the two groups according to the normality test results, and the Kruskal-Wallis test was used in case of more than two groups. The Dunn-Bonferroni approach was used, and multiple comparison procedures were applied in the sub-group analysis among the groups following the Kruskal-Wallis test. Pearson chi-square test, Fisher's exact chi-square test and Fisher-Freeman-Halton tests were used for a comparison of the categorical variables among the groups. The internal consistency of EUROPEP and the Individual Innovativeness Scale was analyzed with the Cronbach alpha coefficient. General scale reliability was determined as $\alpha=0.94$ in the analysis made to examine the reliability of the EUROPEP scale. On the other hand, the results of sub-scale analysis were found to be: $\alpha=0.94$ for doctor-patient sub-dimension, $\alpha=0.86$ for health services sub-dimension, $\alpha=0.88$ for information and support sub-dimension, $\alpha=0.69$ for health service organization sub-dimension and $\alpha=0.83$ for accessibility sub-dimension. Scale reliability for the individual innovativeness questionnaire was $\alpha=0.85$. The relationship between continuous variables was analyzed with correlation analysis, and the
Spearman correlation coefficient was calculated. The SPSS program was used for statistical analysis (IBM Corp. Released 2012. IBM SPSS Statistics for Windows, Version 21.0. Armonk, NY: IBM Corp.). $p<0.05$ was accepted as statistically significant.

\section{Results}

A total of 469 participants ( 273 female and 196 male) were included in the study. 31 people who left the survey incomplete were excluded. The mean age of the participants was calculated as $35.91 \pm 12.11 .79 .5 \%$ of the individuals declared that they were married, $17.5 \%$ were single and $3 \%$ were divorced or widowed. $84.4 \%$ of the individuals indicated that their economic condition was at a medium level. The educational levels of the volunteers were classified as high school graduate at maximum quantity and post-graduate at minimum quantity (Table 1).

\begin{tabular}{|l|l|}
\hline \multicolumn{2}{|l|}{ Table 1. Socio-demographic characteristics of the participants } \\
\hline & $n=469$ \\
\hline Gender (Female/Male) & $273(58.20 \%) / 196(41.80 \%)$ \\
\hline Age (year) & $35.91 \pm 12.11(18: 65)$ \\
\hline Age Groups & \\
$<20$ & $26(5.5 \%)$ \\
$20-29$ & $133(28.4 \%)$ \\
$30-39$ & $155(33 \%)$ \\
$40-49$ & $82(17.5 \%)$ \\
$50-59$ & $43(9.2 \%)$ \\
$\geq 60$ & $30(6.4 \%)$ \\
\hline Marital status & \\
Married & $373(79.5 \%)$ \\
Single & $82(17.5 \%)$ \\
Divorced/widowed & $14(3 \%)$ \\
\hline Education Level & \\
Literate & $15(3.2 \%)$ \\
Primary school & $108(23 \%)$ \\
Secondary school & $67(14.1 \%)$ \\
High school & $146(31.1 \%)$ \\
University & $124(26.4 \%)$ \\
Graduate & $9(1.9 \%)$ \\
\hline Economic Status & \\
Very low & $7(1.5 \%)$ \\
Low & $45(9.6 \%)$ \\
Intermediate & $396(84.4 \%)$ \\
High & $19(4.1 \%)$ \\
Very high & $2(0.4 \%)$ \\
\hline
\end{tabular}

Data $n(\%)$, mean \pm standard deviation (minimum : maximum).

$69.5 \%$ of the participants made the decision of changing their physician themselves. Distance (52.7\%), education (25.8\%) and gender $(16 \%)$ were declared as the most important reasons to change the family physician (Table 2 ).

\begin{tabular}{|l|l|}
\hline \multicolumn{2}{|c|}{ Table 2. Distribution of decisions to change the family physician } \\
\hline Reason for changing the family physician & $n=469$ \\
\hline $\begin{array}{c}\text { Distance } \\
\text { Yes } \\
\text { No }\end{array}$ & $247(52.7 \%)$ \\
\hline $\begin{array}{c}\text { Gender (female physician) } \\
\text { Yes } \\
\text { No }\end{array}$ & $222(47.3 \%)$ \\
\hline $\begin{array}{c}\text { Religion } \\
\text { Yes } \\
\text { No }\end{array}$ & $75(16 \%)$ \\
\hline $\begin{array}{c}\text { Training family health center } \\
\text { Yes }\end{array}$ & $394(84 \%)$ \\
No & $11(2.3 \%)$ \\
\hline
\end{tabular}




\begin{tabular}{|l|l|}
\hline \multicolumn{2}{|c|}{ Table 2. Distribution of decisions to change the family physician } \\
\hline Reason for changing the family physician & $n=469$ \\
\hline $\begin{array}{l}\text { Residential care patient } \\
\text { Yes }\end{array}$ & $17(3.6 \%)$ \\
No & $452(96.4 \%)$ \\
\hline Home visit & \\
Yes & $18(3.8 \%)$ \\
No & $451(96.2 \%)$ \\
\hline
\end{tabular}

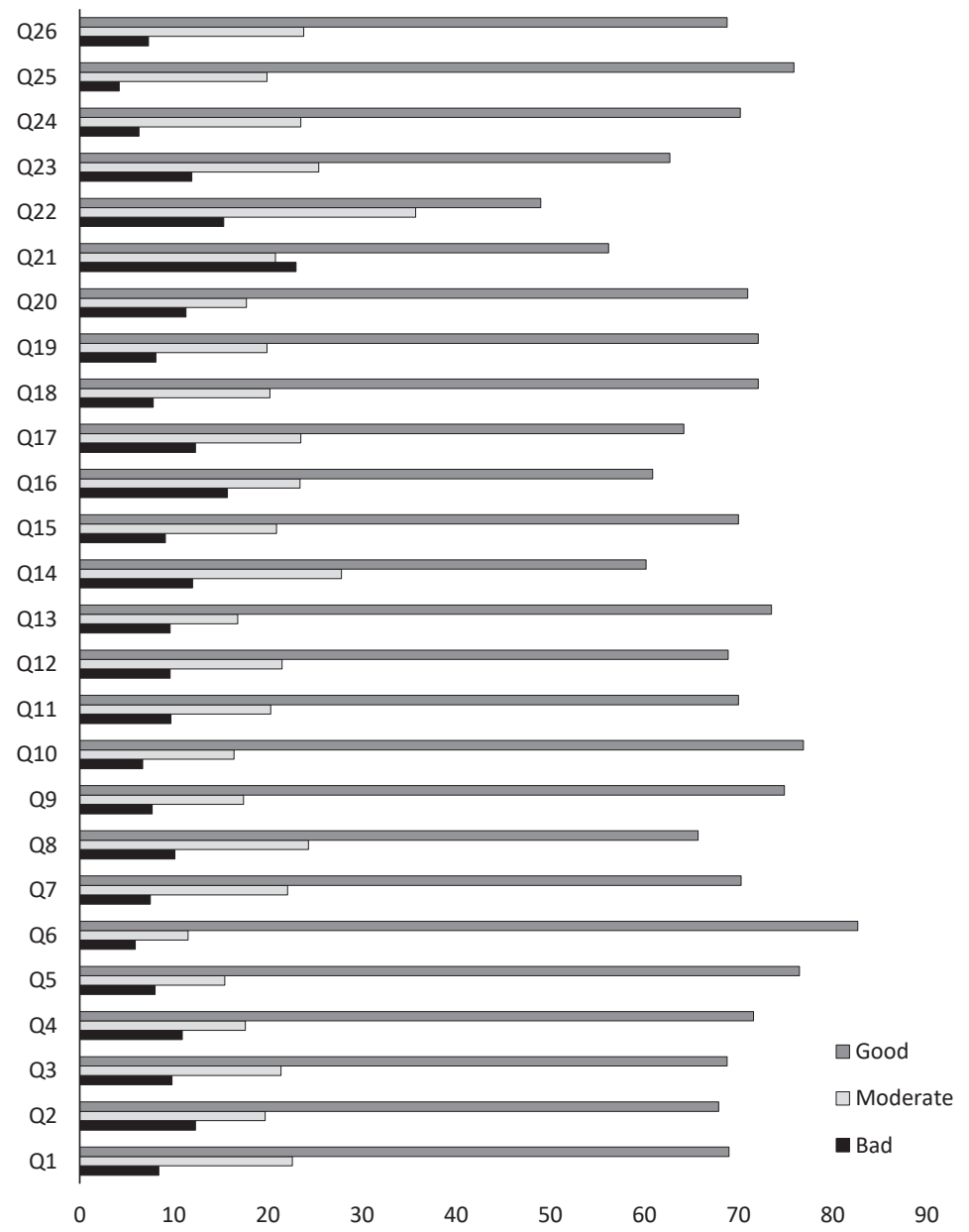

When the questions left unanswered by the participants were excluded, total satisfaction according to the EUROPEP scale was $69 \%$. The issues on which satisfaction was maximum according to the mean scores of the answers given on the EUROPEP scale questions were: 'keeping your records and information confidential', 'listening to you', 'physical examination', while 'being able to speak to the GP on the telephone' and 'waiting time in the waiting room' were issues for which dissatisfaction was high (Figure 1, 2).
Figure 1. Satisfaction ratios according to the EUROPEP scale [\%]

Q1 - making you feel you had time during consultations, Q2 - interest in your personal situation, Q3 - making it easy to talk about your problems, Q4 - involving you in decisions about medical care, Q5 - listening to you, Q6 - keeping your records and data confidential, Q7 - quick relief of your symptoms, Q8 - helping to perform your normal daily activities, Q9 - thoroughness, Q10 - physical examination, Q11 - offering you services for prevention, Q12 - explaining the purpose of tests and treatments, Q13 - discussing your symptoms and/or illness, Q14 - help in dealing with emotional problems, Q15 - helping understand the importance of following advice, Q16 - knowing what has been done during previous contacts, Q17 - preparing what to expect from specialists, Q18 - the helpfulness of the staff, Q19 getting an appointment that suits you, Q20 - getting through to the practice on the phone, Q21 - being able to speak to the GP on the telephone, Q22 - waiting time in the waiting room, Q23 - quick service for urgent health problems, Q24 - general behavior of the doctor in the family practice, Q25 - health services in general, Q26 - physical conditions of the family practice.

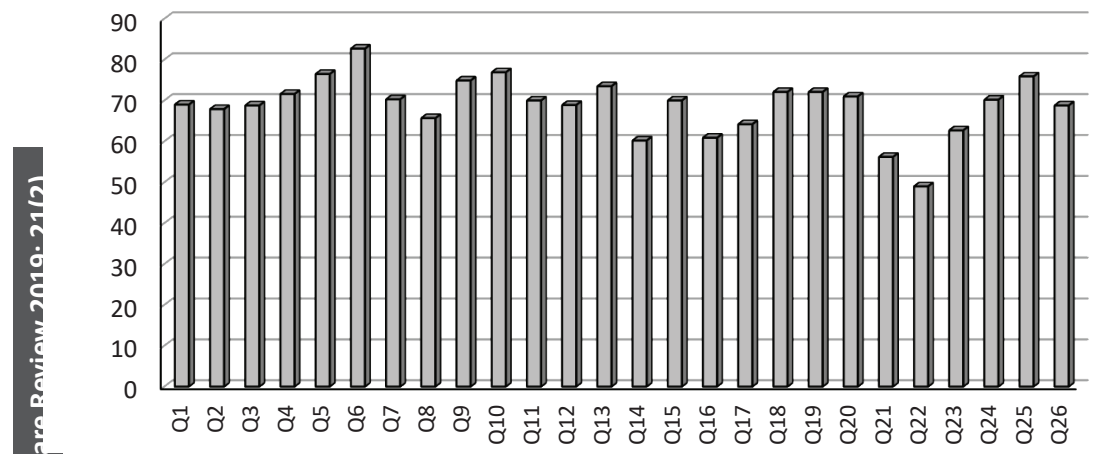

Figure 2. Satisfaction ratios of participants according to the EUROPEP scale [\%]

Q1 - making you feel you had time during consultations, Q2 - interest in your personal situation, Q3 - making it easy to talk about your problems, Q4 - involving you in decisions about medical care, Q5 - listening to you, Q6 - keeping your records and data confidential, Q7 - quick relief of your symptoms, Q8 - helping to perform your normal daily activities, Q9 - thoroughness, Q10 - physical examination, Q11 - offering you services for prevention, Q12 - explaining the purpose of tests and treatments, Q13 - discussing your symptoms and/or illness, Q14 - help in dealing with emotional problems, Q15 - helping understand the importance of following advice, Q16 - knowing what has been done during previous contacts, Q17 - preparing what to expect from specialists, Q18 - the helpfulness of the staff, Q19 - getting an appointment that suits you, Q20 - getting through to the practice on the phone, Q21 - being able to speak to the GP on the telephone, Q22 - waiting time in the waiting room, Q23 - quick service for urgent health problems, Q24 - general behavior of the doctor in the family practice, Q25 - health services in general, Q26 - physical conditions of the family practice. 
The questions that were most often left unanswered were 'reaching your doctor by phone', 'reaching the family health center by phone', 'doctor informing the patient about expectations from referral to a specialist or hospital' and 'keeping your records and information confidential' (Figure 3 ).

There was no difference between the gender groups in terms of general patient satisfaction. According to the sub-group analysis, the satisfaction rate of male patients was higher than female patients in the sub-groups of doctor-patient relationship, health services, information and support. No difference was detected among the satisfaction rates of gender groups in terms of health service organization and accessibility.

Among the participants, innovator was determined as $2.3 \%$, pioneer as $20.4 \%$, interrogator as $57.1 \%$, skeptical as $18.3 \%$ and traditionalist as $1.7 \%$. There was no difference among the innovativeness groups in terms of gender distribution.
There was no difference among the innovativeness sub-groups in terms of general satisfaction rates. In the sub-group analysis, a difference was detected among the innovativeness groups in terms of satisfaction with health service organizations. It was also found that the satisfaction rates of the innovator, pioneer, interrogator and skeptical groups were higher than that of the traditionalist group $(p=0.013, p=0.008, p=0.008$ and $p=0.047$, respectively) (Table 3 ).

There was no difference between general satisfaction and satisfaction sub-groups among innovativeness search sub-groups in terms of age. There was no difference between general satisfaction and satisfaction sub-groups in terms of educational level. There was a direct relation between patient education level and innovativeness scale score. As the education level increased, the score of the innovativeness scale increased $(r=0.34 ; p<0.001)$.

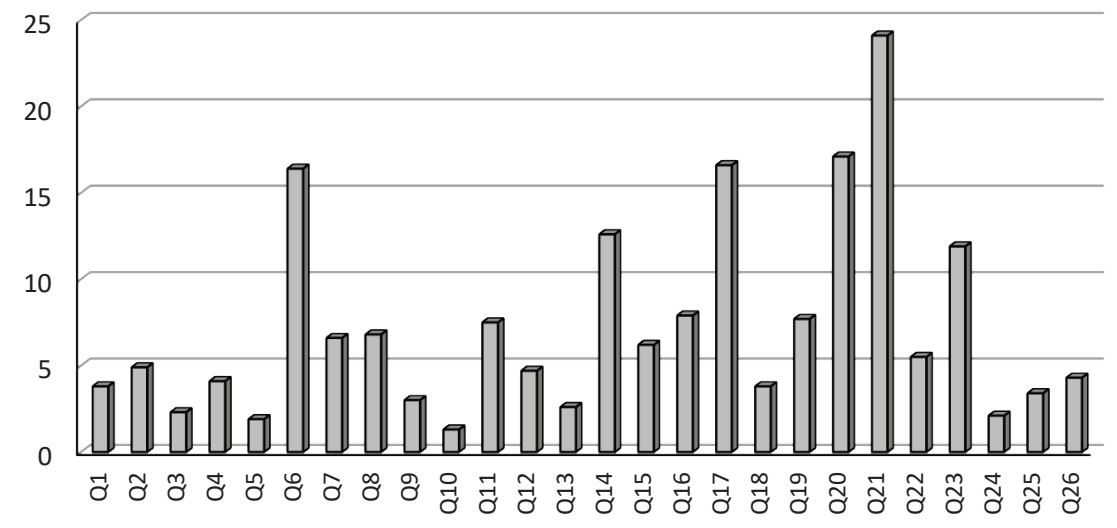

Figure 3. Non-response ratios to the questions of the EUROPEP scale [\%]

Q1 - making you feel you had time during consultations, Q2 - interest in your personal situation, Q3 - making it easy to talk about your problems, Q4 - involving you in decisions about medical care, Q5 - listening to you, Q6 - keeping your records and data confidential, Q7 - quick relief of your symptoms, Q8 - helping to perform your normal daily activities, Q9 - thoroughness, Q10 - physical examination, Q11 - offering you services for prevention, Q12 - explaining the purpose of tests and treatments, Q13 - discussing your symptoms and/or illness, Q14 - help in dealing with emotional problems, Q15 - helping understand the importance of following advice, Q16 - knowing what has been done during previous contacts, Q17 - preparing what to expect from specialists, Q18 - the helpfulness of the staff, Q19 - getting an appointment thatsuits you, Q20 - getting through to the practice on the phone, Q21 - being able to speak to the GP on the telephone, Q22 - waiting time in the waiting room, Q23 - quick service for urgent health problems, Q24 - general behavior of the doctor in the family practice, Q25 - health services in general, Q26 - physical conditions of the family practice.

\begin{tabular}{|c|c|c|c|c|c|c|}
\hline & $\begin{array}{l}\text { Innovator } \\
n=11\end{array}$ & $\begin{array}{l}\text { Pioneer } \\
n=96\end{array}$ & $\begin{array}{l}\text { Interrogator } \\
n=268\end{array}$ & $\begin{array}{l}\text { Skeptical } \\
n=86\end{array}$ & $\begin{array}{l}\text { Traditionalist } \\
n=8\end{array}$ & $p$ \\
\hline $\begin{array}{l}\text { Patient Satisfaction (General) } \\
\text { Satisfied } \\
\text { Unsatisfied }\end{array}$ & $\begin{array}{l}7(63.6 \%) \\
4(36.4 \%) \\
\end{array}$ & $\begin{array}{l}32(33.3 \%) \\
64(66.7 \%) \\
\end{array}$ & $\begin{array}{l}83(31 \%) \\
185(69 \%) \\
\end{array}$ & $\begin{array}{l}20(23.3 \%) \\
66(76.7 \%) \\
\end{array}$ & $\begin{array}{l}2(25 \%) \\
6(75 \%) \\
\end{array}$ & $0.089^{a}$ \\
\hline $\begin{array}{l}\text { Patient Satisfaction } \\
\text { (Physician-Patient Relation) } \\
\text { Satisfied } \\
\text { Unsatisfied }\end{array}$ & $\begin{array}{l}9(81.8 \%) \\
2(18.2 \%) \\
\end{array}$ & $\begin{array}{l}46(47.9 \%) \\
50(52.1 \%)\end{array}$ & $\begin{array}{l}138(51.5 \%) \\
130(48.5 \%)\end{array}$ & $\begin{array}{l}36(41.9 \%) \\
50(58.1 \%)\end{array}$ & $\begin{array}{l}2(25 \%) \\
6(75 \%) \\
\end{array}$ & $0.060^{a}$ \\
\hline $\begin{array}{l}\text { Patient Satisfaction (Health Services) } \\
\text { Satisfied } \\
\text { Unsatisfied }\end{array}$ & $\begin{array}{l}8(72.7 \%) \\
3(27.3 \%)\end{array}$ & $\begin{array}{l}45(46.9 \%) \\
51(53.1 \%) \\
\end{array}$ & $\begin{array}{l}142(53 \%) \\
126(47 \%)\end{array}$ & $\begin{array}{l}42(48.8 \%) \\
44(51.2 \%)\end{array}$ & $\begin{array}{l}2(25 \%) \\
6(75 \%)\end{array}$ & $0.257^{a}$ \\
\hline $\begin{array}{l}\text { Patient Satisfaction } \\
\text { (Information and Support) } \\
\text { Satisfied } \\
\text { Unsatisfied }\end{array}$ & $\begin{array}{l}8(72.7 \%) \\
3(27.3 \%)\end{array}$ & $\begin{array}{l}44(45.8 \%) \\
52(54.2 \%)\end{array}$ & $\begin{array}{l}140(52.2 \%) \\
128(47.8 \%)\end{array}$ & $\begin{array}{l}35(40.7 \%) \\
51(59.3 \%)\end{array}$ & $\begin{array}{l}2(25 \%) \\
6(75 \%) \\
\end{array}$ & $0.087^{a}$ \\
\hline $\begin{array}{l}\text { Patient Satisfaction } \\
\text { (Health Service Organization) } \\
\text { Satisfied } \\
\text { Unsatisfied }\end{array}$ & $\begin{array}{l}7(63.6 \%) \\
4(36.4 \%)\end{array}$ & $\begin{array}{l}47(49 \%) \\
49(51 \%)\end{array}$ & $\begin{array}{l}130(48.5 \%) \\
138(51.5 \%)\end{array}$ & $\begin{array}{l}34(39.5 \%) \\
52(60.5 \%)\end{array}$ & $\begin{array}{l}0 \\
8(100 \%)\end{array}$ & $0.023^{a}$ \\
\hline $\begin{array}{l}\text { Patient Satisfaction (Accessibility) } \\
\text { Satisfied } \\
\text { Unsatisfied }\end{array}$ & $\begin{array}{l}7(63.6 \%) \\
4(36.4 \%)\end{array}$ & $\begin{array}{l}29(30.2 \%) \\
67(69.8 \%)\end{array}$ & $\begin{array}{l}82(30.6 \%) \\
186(69.4 \%)\end{array}$ & $\begin{array}{l}23(26.7 \%) \\
63(73.3 \%)\end{array}$ & $\begin{array}{l}1(12.5 \%) \\
7(87.5 \%)\end{array}$ & $0.143^{a}$ \\
\hline
\end{tabular}

\footnotetext{
a - Fisher-Freeman-Halton Test.
} 
There was no relation between the number of family physician changes and patient satisfaction $(p=0.858)$ and innovativeness $(p=0.520)$.

\section{Discussion}

In the current study, we found that patient satisfaction and individual innovativeness did not have an effect on the decision to change family physicians. Distance, education and gender are at the forefront in family physician preference.

In this study, the satisfaction rate was $69 \%$. Since the EUROPEP scale does not have a previously determined cut-off point, general satisfaction was evaluated on an answer basis, not a mean basis. In previous studies, satisfaction with the family medicine system was $89.5 \%$ in Bursa, $80.7 \%$ in Malatya and $87.5 \%$ in Gumushane [15-17]. As the volunteers are those who refer in order to change their family physician, a low level of satisfaction can be considered as an expected situation.

The factor that patients often consider important in physician selection is ease of access (practice hours, distance from home and seeing the doctor without delay). The most highly disputed issue in the studies is distance or appropriate location. Another important issue is that patients prefer physicians they can reach via their own transport or public transport vehicles [18-20]. Other factors are parking area $[19,20]$ and transport fee $[21,22]$. Other socio-demographic factors that are considered important are age and gender of the physician (whether the physician is the same gender as the patient). Generally, it is assumed that the demographic parameters of the physician affect the selection of a physician by patients, but other factors are considered more important $[23,24]$. However, it is shown that individuals generally tend to prefer physicians that are the same age and gender as themselves [3]. In the current study, $16 \%$ of the participants answered the question "was your decision of changing the physician affected because the physician was female" with "yes".

In general, while factors associated with a physician's individual characteristics (e.g. gender, religion, marital status) are considered relatively unimportant, variables associated with a physician's professional expertise (e.g. board certificate or specialist physician) are considered much more [7]. Research indicates that individuals are mostly interested in the education of the physician, among the non-organizational factors, in their decision about family physicians $[20,25] .25 .8 \%$ of the patients indicated that family medicine residency education in the family health center positively affected their decision to change physician.

In a study performed on prospective teachers, it was shown that the difference between the individual innovativeness characteristics of the participants and the current grade they work with is significant. According to this, the mean scale score of fourth grade prospective teachers was higher than that of first grade prospective teachers [26]. In the current study, the relation between patient education level and the innovativeness scale score was also in the same direction. The innovativeness scale score increases as the education level increases. In the same study, it was shown that there is a positive and medium-level relation between the critical thinking tendency of prospective teachers and their individual innovativeness [26]. In our study, we did not detect a relation between patient satisfaction and individual innovativeness search with the number of physician changes.

\section{Strengths and limitations of the study}

The current research is a leading study examining innovativeness, which may have an effect on the decision to change the family physician. Some limitations of the study can be listed as follows: the study was applied to patients visiting the family physician. Hence, satisfaction and innovativeness in this study refers to the satisfaction and innovativeness of people utilizing the family healthcare unit. A control group would be better to compare the results obtained in the study. The single-centeredness of the study is another important limitation preventing the generalizability of the results.

\section{Conclusions}

Individual innovativeness is not a factor forcing individuals to change their family physician in our region. Distance, education and gender are at the forefront in family physician preference. Patients prioritize receiving service from trained family physicians. These issues should be taken into account while planning the future of family practice.

Source of funding: This work was funded from the authors' own resources.

Conflicts of interest: The authors declare no conflicts of interest.

\section{References}

1. Starfield B, Shi L, Macinko J. Contribution of primary care to health systems and health. The Milbank Q 2005; 83(3): 457-502.

2. Kringos $D$, Boerma W, Bourgueil $\mathrm{Y}$, et al. The strength of primary care in Europe: an international comparative study. Br J Gen Pract 2013; 63(616): 742-750.

3. Victoor A, Delnoij MJD, Friele DR. et al. Determinants of patient choice of healthcare providers: a scoping review. BMC Health Serv Res 2012; 12: 272, doi: 10.1186/1472-6963-12-272.

4. Wolinsky FD, Steiber SR. Salient issues in choosing a new doctor. Soc Sci Med 1982; 16: 759-767.

5. Salisbury CJ. How do people choose their doctor? Br Med J 1989; 299: 608-610.

6. Billinghurst B, Whitfield $\mathrm{M}$. Why do patients change their general practitioner? A postal questionnaire study of patients in Avon. $\mathrm{Br}$ J Gen Pract 1993; 43: 336-338.

7. Bornstein BH, Marcus D, Cassidy W. Choosing a doctor: an exploratory study of factors influencing patients' choice of a primary care doctor. J Eval Clin Pract 2000; 6: 255-262.

8. Güngör G, Göksu A. Kamu inovasyon uygulaması: Türkiye örneği [cited 29.01.2019]. Available from URL: http://docplayer.biz. tr/5389102-Kamu-inovasyon-uygulamasi-turkiye-ornegi.html (in Turkish).

9. Ekonomik İşbirliğive Kalkınma Örgütü, Avrupa Birliği İstatistik Ofisi. Oslo Kılavuzu: Yenilik Verilerinin Toplanması ve Yorumlanması İçin ilkeler, 3. Baskı, 2005: 93-107 (in Turkish).

10. Ottenbacher M, Gnoth J. How to develop successful hospitality innovation. Cornell Hotel and Restaurant Administration Quarterly 2005; 46: 205-222.

11. Luecke R. Managing Creativity and Innovation. Çeviri: Parlak T. İş Dünyasında Yenilikve Yaratıcılık. 1. Baskı. İstanbul, Türkiye İ̧̧ Bankası Kültür Yayınları 2008: 3-9 (in Turkish).

12. Hurt HT, Joseph K, Cook CD. Scales for the measurement of innovativeness. Human Communication Research 1977; 4: 58-65.

13. Kılıçer K. Teknolojik yeniliklerin yayılmasını ve benimsenmesini arttran etmenler. Anadolu Üniversitesi Sosyal Bilimler Dergisi 2008; 8: 209-222 (in Turkish). 
14. Aktürk Z. Hastalar Hekimlerini Değerlendiriyor, EUROPEP Ölçeği. DEU Tıp Fakültesi Dergisi 2002; 153-160 (in Turkish).

15. Birinci Basamak Sağlık Hizmetlerinde Hasta Memnuniyeti; 2012: 2-3 [cited 08.12.2017]. Available from URL: http://www.sagem.gov. tr/europeprapor.03032014.pdf(in Turkish).

16. Mete B, Pehlivan E, Tekin Ç, et al. Satisfaction levels of the adults who benefit from the family medicine care in Malatya city center and the factors that affect it. Med Science 2015; 4(4): 2721-2731.

17. Bostan S, Havvatoğlu K. Europep aile hekimliği memnuniyet ölçeğine göre Gümüşhane aile hekimliği memnuniyet araştırması. Gümüşhane Üniversitesi Sağlık Bilimleri Dergisi 2014; 3(4): 1067-1078 (in Turkish).

18. Mohan G, Nolan A, Lyons S. An investigation of the effect of accessibility to General Practitioner services on healthcare utilisation among older people. Soc Sci Med 2019; 220: 254-263.

19. Dijs-Elsinga J, Otten W, Versluijs M, et al. Choosing a hospital for surgery: the importance of information on quality of care. Med Decis Making 2010; 30(5): 544-555, doi: 10.1177/0272989X09357474.

20. Shah J, Dickinson CL. Establishing which factors patients value when selecting urology outpatient care. Br J Med Surg Urol 2010; 3: 25-29.

21. Exworthy M, Peckham S. Access, choice and travel: implications for health policy. Soc Pol Admin 2010; 40: $267-287$.

22. Krupat E, Stein T, Selby JV, et al. Choice of a primary care physician and its relationship to adherence among patients with diabetes. Am J Manag Care 2002; 8: 777-784.

23. Bernard ME, Sadikman JC, Sadikman CL. Factors influencing patients' choice of primary medical doctors. Minn Med 2006; 89: 46-50.

24. Johnson A, Schnatz P, Kelsey A, et al. Do women prefer care from female or male obstetrician-gynecologists? A study of patient gender preference. BMC Med Educ 2005; 105: 369-379.

25. Howell E, Gardiner B, Concato J. Do women prefer female obstetricians? Obstet Gynecol 2002; 99: 1031-1035.

26. Özgür H. Bilişim Teknolojileri Öğretmen Adaylarının Eleştirel Düşünme Eğilimleri ile Bireysel Yenilikçilik Özellikleri Arasındaki Ilişsinin Çeşitli Değişkenler Açısından İncelenmesi. Mersin Üniversitesi Eğitim Fakültesi Dergisi 2013; 9(2): 409-420 (in Turkish).

Tables: 3

Figures: 3

References: 26

Received: 14.01.2019

Reviewed: 27.01 .2019

Accepted: 4.02 .2019

Address for correspondence:

Hakan Demirci, MD

Department of Family Medicine

University of Health Sciences

Bursa Yüksek Ihtisas Training and Research Hospital

Bursa

Turkey

Tel.: 00905368963330

E-mail: drhakandemirci@hotmail.com 